\title{
Synergistic Effect of Indoleacetic Acid and Kinetin on the Primary Thickening of Pea Stem Segments
}

\author{
by Tohru HaShIMOTo*
}

Received August 29, 1960

Since the discovery of auxins as growth regulators of plant stems, many studies have been accumulated on the growth of stem in connection with auxin action. However, attention of investigators has generally been directed almost to extension growth, i.e. increase in length of the stem, but not to thickening growth or increase in thickness. Although, the thickening of stems has been dealt with by some investigators including Snow, Söding, and Avery et al. (refer to Söding ${ }^{1}$ ), and Meyer and Anderson $\left.^{2}\right)$ ), their studies have been restricted to the secondary thickening growth in connection with the cambium activity of stems, and no information is available on the control of a primary thickening in stems by a growth substance or substances.

In the shoot of plants the apical meristem produces young cells. The cells, being at first very small, show an increase in size. If the increase takes place in the longitudinal direction, this process results in extension growth of the stem, and if in the lateral direction, an increase in thickness of the stem appears. It has been established that the former process is regulated by auxins, whereas no substance is thus far known that controls the latter, although it is probable that a substance or substances control the increase in cell size in the lateral direction of the stem. The present paper describes that kinetin exerts in the pea stem such an action as the presumable substance in the presence of indoleacetic acid (IAA).

\section{Experimental}

As the material stem and petiole segments of Pisum sativum L. var. Alaska were used. The seedlings were cultivated in pots containing field soil in a greenhouse at $15-25^{\circ}$. The seedlings were harvested when their petioles attached to the sixth nodes were upright, the leaflets of the sixth leaf were not completely unfolded, and the sixth internode did not appear yet. A single segment of $5.2 \mathrm{~mm}$. in length was cut from the fifth internode ca. $5 \mathrm{~mm}$. below the apical node and from the middle portion of the uppermost petiole. Two leaf discs, $5.0 \mathrm{~mm}$. in diameter and not including the midrib, were punched out with a cork borer from one leaflet. The stem segment from the seventh internode was likewise prepared when the internode was at the same growth stage as that of the above-mentioned fifth internode. All these materials were at a stage of vigorous growth. More detailed description on the materials was presented in the previous paper $\left.{ }^{3}\right)$.

The three sorts of materials thus prepared were floated on $10 \mathrm{~m} l$. of culture medium for incubation. In the case of leaf discs care was taken to place the discs upper surface up. As the medium, was used Boysen-Jensen's culture solution containing 2 per cent sucrose with or without the addition of IAA, kinetin or the combination of the two. The incubation was performed for 18 hours under about 1,000 lux at $25^{\circ}$. The illumination was supplied by white fluorescent tubes (Toshiba Co.).

After the incubation, measurements were made of the length, diameter and fresh

* Biological Laboratory, Musashi University, Nerima.ku, Tokyo, Japan. 
weight of the segments, and of the area and fresh weight of the leaf discs. The length and diameter of the segments were determined with a low power binocular microscope, and the fresh weight, with a micro-torsion balance. The area of leaf discs was estimated from weight of cut shadow graphs on uniform printing paper.

For microscopic observation, 6 stem segments of average size were selected from each of the treated and control lots as well as from the materials before incubation and were fixed in FAA, dehydrated in tertiary butyl alcohol series and embedded in paraffin according to Sass's text-book ${ }^{4}$ ). Serial cross sections, $15 \mu$ in thickness, were prepared and were stained with Heidenhain's iron haematoxylin. This dehydration method was recommended as an ideal one causing only a very small shrinking of samples.

\section{Results}

IAA-induced increase in length of the stem and petiole segments is inhibited by the addition of kinetin. As seen from Fig. 1 and Fig. 2, this inhibition by kinetin increases with the increasing concentration of kinetin and, in the stem, almost completely nullifies the action of $10 \mathrm{ppm}$ IAA (the optimum concentration for the extension growth) at concentrations above $0.3 \mathrm{ppm}$ of kinetin. Although in the petiole the maximum inhibition is smaller than in the stem, a similar trend is observed in the curves. This antagonism of kinetin and IAA in the extension growth is quite in agreement with de Ropp's result ${ }^{5}$ ) obtained with the fragments of Helianthus hypocotyl. The increase in fresh weight which occurs as a result of the IAA application, on the other hand, is not inhibited by kinetin even at $0.3 \mathrm{ppm}$, a concentration high enough to abolish the IAA-induced increase in length.

When a fresh weight per unit length of stem segments is computed, it is easily found to be much larger in IAA-kinetin-treated segments than in IAA-treated or in kinetin-treated ones (Fig. 4). The increase in fresh weight per unit length probably means that the thickening of the segments took place.

The direct determination of the diameter of the stem manifests, as shown in Fig. 5, that an increase in thickness is really caused. The optimum concentration of kinetin is $0.3 \mathrm{ppm}$ at the dose of $10 \mathrm{ppm}$ IAA, and at concentrations above $0.3 \mathrm{ppm}$ the effect of kinetin rather decreases. To be noted especially is that in the absence of IAA this effect of kinetin is never observed and kinetin requires IAA to induce the thickening growth of the stem. Fig. 6 demonstrates that this effect of kinetin and IAA is reproduced in the petiole segments as well. In Fig. 7 the photographs of the kinetin-IAA-treated and untreated stem segments are shown.

The growth in thickness of the stem and petiole segments is slightly brought about by IAA alone, but when kinetin which is quite ineffective in itself is added together with IAA, a remarkable increase in the thickness is obtained. IAA and kinetin act antagonistically on the elongation, but synergistically on the thickening of stem and petiole. This fact suggests that the stem and petiole have different properties for growth between the longitudinal and transverse directions.

The expansion of leaves is stimulated by either kinetin ${ }^{6,7,8}$ ) or IAA $^{3}$ ). A synergism between these substances has been also reported in the expansion of radish leaf discs ${ }^{9}$. As shown in Table 1, the corresponding result was obtained in the pea leaf discs, too. In this experiment IAA was added at $10 \mathrm{ppm}$, the optimum concentration for the expansion of the leaf $\left.\operatorname{discs}^{3}\right)$. Even when solely applied, kinetin is effective. This can be considered, judging from the result obtained with the thickening of the stem segments, that kinetin exerts the action in combination with endo- 

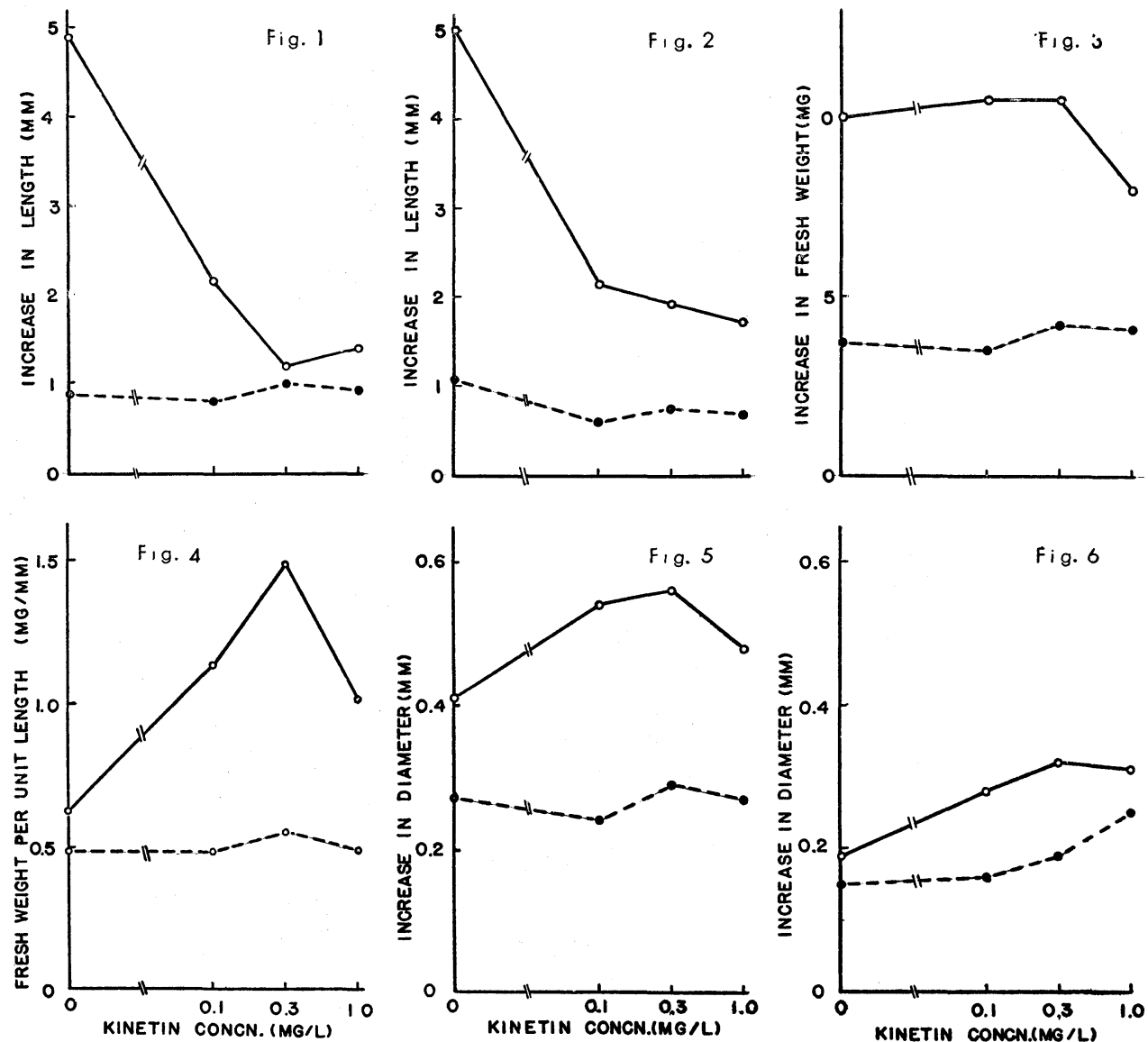

Figs. 1, 2. Effect of kinetin on the IAA-induced increase in length of the stem and petiole segments.

Fig. 3. Effect of kinetin on the increase in fresh weight of the stem segments in the presence and absence of IAA. The initial fresh weight of a stem segment is $6.41 \mathrm{mg}$.

Fig. 4. Effect of kinetin on the increase in fresh weight per unit length of the stem segments in the presence and absence of IAA. The initial fresh weight per unit length of a stem segment is $1.23 \mathrm{mg}$.

Figs. 5, 6. Effect of kinetin in the presence and absence of IAA on the increase in diameter of the stem and petiole segments. Their initial diameters are 1.28 and $1.12 \mathrm{~mm}$., respectively. Figs. 1-6. The solid and broken lines indicate the data in the presence and absence of IAA, respectively. IAA concentration administered was always $10 \mathrm{ppm}$. The incubation was made for 18 hours under ca. 1,000 lux white fluorescent light at $25^{\circ}$.

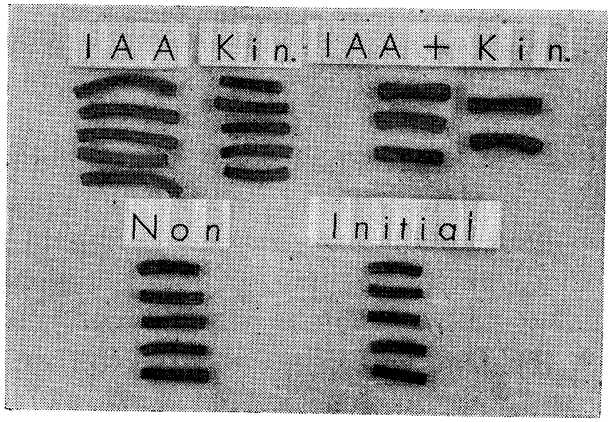

Fig. 7. The photographs of IAA-treated, kinetin-treated and IAA-kinetin-treated stem segments. The photographs of untreated stem segments and the segments before incubation are shown for comparison. A distinguished thickening is seen in the IAA-kinetin-treated segments. The concentrations of IAA and kinetin administered were 10 and $0.3 \mathrm{ppm}$, respectively. 
Table 1. The Synergistic effect of kinetin and IAA on the expansion of pea leaf discs. The concentrations of kinetin and IAA are 1 and $10 \mathrm{ppm}$, respectively. Each figure indicates the increase as per cent of that of control during 20 hour culture.

\begin{tabular}{l|c|c}
\hline \multicolumn{1}{c|}{ Treatment } & Fresh weight & Area \\
\hline Control & 100 & 100 \\
Kinetin & 181 & 121 \\
IAA & 172 & 129 \\
Kinetin +IAA & 208 & 138 \\
\hline
\end{tabular}

genous auxin, at least, indoleacetic acid therein.

For the purpose of obtaining more detailed information about the thickening of the stem induced by simultaneous administration of kinetin and IAA from the histological viewpoint, a microscopical observation was made on the serial cross sections of the stem segments. Using the microscope equipped with a micrometer the diameter and the number of cell layers along the diameter of the treated segments were determined in comparison with those of control and those before incubation. In the case of the segments from the seventh internodes the distance from the epidermis to the innermost layer of the pith and number of layers of cells therein were adopted for measurement, since the segments have the pith-cavity in the centre. As seen in Fig. 8, the cross section of the stem is a square with large vascular bundles in the corners. The measurement was carried out through the interfascicular region as indicated by the line in the figure.

To the microscopic observation six stem segments were submitted from each lot, and of the serial sections of each segment were examined the following ten sections: 3 sections from the part near one end of the segment, 3 sections from the part near

Table 2. The results of the microscopic examination on the cross sections of

IAA-kinetin-treated and untreated stem segments, and of those before

incubation. The culture of the segments was made for 18 hours under ca. 1,000 lux white fluorescent light at $25^{\circ}$. The concentrations of IAA and kinetin administered were 10 and $0.3 \mathrm{ppm}$, respectively.

\begin{tabular}{|c|c|c|c|c|}
\hline & & $\mathrm{IAA}+$ kinetin & Untreated & $\begin{array}{c}\text { Before } \\
\text { incubation }\end{array}$ \\
\hline $\begin{array}{l}5 \text { th } \\
\text { internode }\end{array}$ & $\begin{array}{l}\text { Diameter (mm.) } \\
\text { No. of layers }\end{array}$ & $\begin{array}{l}1.12 \pm 0.03^{*} \\
25.5 \pm 0.7\end{array}$ & $\begin{aligned} 0.87 & \pm 0.02 \\
25.3 & \pm 0.5\end{aligned}$ & $\begin{array}{l}0.79 \pm 0.01 \\
25.3 \pm 0.7\end{array}$ \\
\hline $\begin{array}{c}\text { 7th } \\
\text { internode }\end{array}$ & $\begin{array}{l}\text { Diameter (mm.) } \\
\text { Distance from epidermis } \\
\text { to innermost layer of } \\
\text { pith (mm.) } \\
\text { Diameter of pith-cavity } \\
\text { (mm.) } \\
\text { No. of layers from epi- } \\
\text { dermis to innermost } \\
\text { layer of pith }\end{array}$ & $\begin{array}{l}1.28 \pm 0.03 \\
0.496 \pm 0.017 \\
0.316 \pm 0.039 \\
12.2 \pm 0.36\end{array}$ & $\begin{array}{l}1.10 \pm 0.03 \\
0.378 \pm 0.013 \\
0.296 \pm 0.033 \\
12.3 \pm 0.34\end{array}$ & \\
\hline
\end{tabular}

* The figures connected by \pm symbol, which were calculated from the standard error of each mean value, indicate 0.95 confidence intervals. 


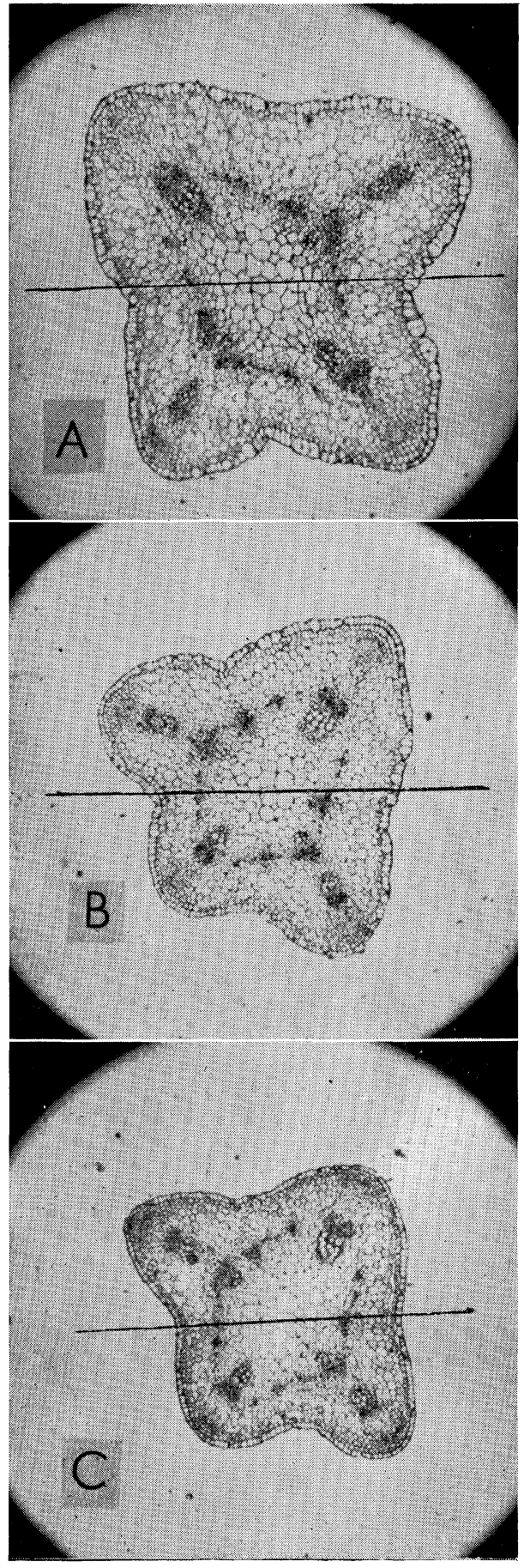

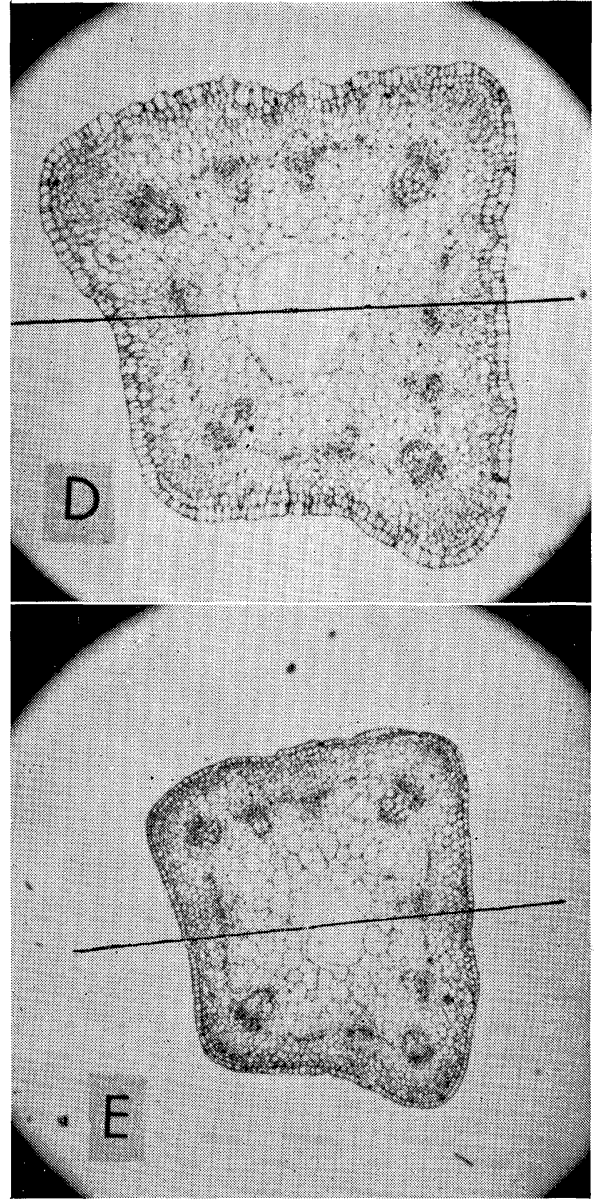

Fig. 8. Microscopic photographs showing the cross sections of IAA-kinetin-treated (A, D) and untreated (B, E) stem segments and of the stem segments before incubation (C). $\mathrm{A}, \mathrm{B}$ and $\mathrm{C}$; the cross sections of the fifth internode. $\mathrm{D}$ and $\mathrm{E}$; the cross sections of the seventh internode. In $\mathrm{A}$ and $\mathrm{D}$ the enlargement of the cells of epidermis, cortex and pith is remarkable. The concentrations of IAA and kinetin administered were 10 and $0.3 \mathrm{ppm}$, respectively. The incubation was made for 18 hours under ca. 1,000 lux white fluorescent light at $25^{\circ}$.

the other end, and 4 sections from the middle part, each section being selected every 17 to 20 sections. Thus an unbiased selection of examined sections was secured. 
The data of the microscopic examination are shown in Table 2. As seen from the table, the thickness of the stem, expressed in terms of the diameter, increases during the 18 hour incubation period even in the control segments, but in the kinetinIAA-treated segments the increase in thickness is much more remarkable. As is observed in Fig. 8, the epidermis, cortex and pith take part in the thickening.

The number of the cell layers, on the other hand, changes during the experimental period neither in the treated nor in the control segments as compared with that of the segments before incubation. Furthermore, no microscopical figure of cell division was seen throughout the section. The above observations indicate that no appreciable number of cell division took place in the incubation period of 18 hours. These findings are the case in the segments not only from the fifth internode but also from the seventh one. Accordingly it is concluded that the increase in thickness of the kinetin-IAA-treated stem segment is, under these experimental conditions, due to an increase in cell size but not in cell number.

\section{Discussion and Conclusion}

It was found that pea stem and petiole segments responded to a simultaneous treatment of kinetin and IAA, though not to either of them alone, by an increase in thickness, without any detectable amount of cell division. This is the first* report that the primary thickening of the stem is induced by growth substances.

Jablonski and Skoog ${ }^{11}$ ) and Naylor et al. ${ }^{12}$ ) have reported that in tobacco pith culture IAA brings about a cell enlargement entirely unaccompanied by cell division. Thereafter, the Wisconsin group including Skoog and Miller has found ${ }^{13-16}$ ) that the addition of kinetin together with IAA to the culture induces cell division. These reports seem to be in discrepancy with the present result. However, if it is considered that they used isolated pith tissues and moreover cultured them as long a period as 3 to 24 days, the above seeming discrepancy in results may be readily explained. In addition Kuraishi and Okumura have reported ${ }^{7}$ ) that the promotion of leaf growth by kinetin is ascribed to cell enlargement. It can be assumed that kinetin has two aspects of action such as cell enlargement and cell division.

To be considered here is the question whether the aspect of the thickening mentioned above really exists in normal plants, under the natural conditions. Esau states $^{17}$ ), referring to the work of Troll and Rauh with herbaceous dicotyledons, that the primary thickening of the axis occurs through cell division and cell enlargement. In dicotyledons and gymnosperms this growth may be rather diffuse, or more or less restricted to the pith or cortex. Ball has found ${ }^{18}$ ) with the stem of Lupinus albus $\mathrm{L}$. that an increase in diameter of the pith which is associated with a thickening of the subapical region of the stem is brought about mainly by an increase in cell size, and an increase in cell number is somewhat less important as a cause of the thickening. These findings evidence that such an aspect of the thickening of stems as due to the increase in cell size really forms an integral part of the process of stem growth.

In fact the region of the stem from which the segment has been excised in the present experiment is in situ in the state of thickening growth as well as of extension growth. When it is excised and cultured on the medium containing sucrose and some minerals essential for plant life, and even when IAA is added, the segment does not show thickening, unless kinetin is added to the culture medium. This fact suggests that this region of the stem makes the growth in thickness by the supply

* Recently Katsumi reported ${ }^{10}$ ) a quite similar result with etiolated pea epicotyl segments. 
of kinetin or kinetin-like substance(s) in situ.

Popp, long ago, reported ${ }^{19}$ ) that a plant receiving higher intensity light produced a thicker stem than that receiving lower intensity light. We also have observed ${ }^{20}$ ) in the dark-grown seedling of broad bean, that brief irradiation by low intensity of incandescent light causes a thickening of the stem of the seedlings as well as an expansion of the leaf. These phenomena are well-known as a feature of prevention of etiolation by light.

Kinetin has such biological actions quite similar to light as stimulation of leaf expansion ${ }^{6-8}$ ), unbending of the apical hook of dark-grown seedlings $s^{6}$ ), inhibition of IAA-induced elongation of the stem ${ }^{5}$ ), promotion of IAA-induced elongation in Avena coleoptiles $^{21,22}$ ), fulfilment, although partial, of nonphotosynthetic light requirement for multiplication of Lemna minor ${ }^{23}$ ), and breaking of seed dormancy ${ }^{6}$ ). In the present study a new action of stimulating the thickening of the stem was added to kinetin as its effects similar to light actions. Although a general occurrence of kinetin in higher plant tissues is thus far not evidenced, it is probable that kinetin or kinetinlike substance(s) plays an important rôle in the thickening of stems.

I wish to express my thanks to Associate Prof. T. Yamaki for his guidance and to Dr. N. Hara for his generous help in making the microscopic preparation. This experiment was done at the Biological Institute, College of General Education, University of Tokyo.

\section{Summary}

The primary thickening of the stem segment of pea (Pisum sativum L. var. Alaska) has been studied from the viewpoint of growth substance and histology. It has been found that the thickening is induced by the simultaneous administration of IAA and kinetin, but not by either of them given separately, and that the thickening is due to an increase in cell size of the epidermis, cortex and pith, unaccompanied by an increase in cell number. It is discussed that the thickening of the intact stem is regulated by kinetin or a kinetin-like substance(s) in the plant in co-operation with endogenous auxin.

\section{References}

1) Söding, H., Die Wuchsstofflehre, Georg Thieme Verlag, Stuttgart (1952). 2) Meyer, B. S., and Anderson, D. B., Plant Physiology 2nd Edit., D. Van Nostrand Co., Inc. (1952). 3) Hashimoto, T., Sci. Pap. Coll. Gen. Educ. Univ. Tokyo 9: 235 (1959). 4) Sass, J. E., Botanical Microtechnique 3rd Edit., The Iowa State College Press, Ames (1958). 5) DeRopp, R. S., Plant Physiol. 31: 253 (1956). 6) Miller, C. O., ibid. 31: 318 (1956). 7) Kuraishi, S., and Okumura, F. S., Bot. Mag. Tokyo 70: 86 (1957). 8) Scott, R. H., Jr., and Liverman, J. L., Plant Physiol. 31: 321 (1956). 9) Kuraishi, S., Sci. Pap. Coll. Gen. Educ. Univ. Tokyo 9: 67 (1959). 10) Katsumi, M., Abstracts of Papers presented at the 24th Annual Meeting of the Botanical Society of Japan, 30 (in Jap.). 11) Jablonski, J. R., and Skoog, F., Physiol. Plantarum 7: 16 (1954). 12) Naylor, J., Sander, G., and Skoog, F., ibid. 7: 25 (1954). 13) Miller, C. O., Skoog, F., von Saltza, M. H., and Strong, F. M., Jour. Amer. Chem. Soc. 77: 1392 (1955). 14) —, - Okumura, F. S., —, and —, ibid. 78: 1375 (1956). 15) Skoog, F., and Miller, C. O., Soc. Exptl. Biol. Symposium, Biological Action of Growth Substances, 11th Symposium, 118 (1957). 16) Das, N. K., Patau, K., and Skoog, F., Physiol. Plantarum 9: 640 (1956). 17) Esau, K.. Plant Anatomy, John Wiley and Sons, Inc., New York (1953). 18) Ball, E., Amer. Journ. Bot. 36: 440 (1949). 19) 
Popp. H. W., Bot. Gaz. 82: 306 (1926). 20) Hashimoto, T., unpublished data. 21) Liverman, J. L., and Bonner, J., Proc. Natl. Acad. Sci., U.S. 39: 905 (1953). 22) Schrank, A. R., Plant Physiol. 32, suppl. xlix (1957). 23) Hillman, W. S., Science 126: 165 (1957).

\section{摘要}

橋本徹：エンドウの茎の 1 次肥大生長に括けるインドール酶酸とカイネチンの相互作用

茎の伸長生長がオーキシンによって促進されることは周知の事実である.また形成層の活動による茎の 二次肥大生長もオーキシンにより調節されていることがわかっている．乙かし形成層による細胞の增殖を 伴わない 1 次肥大生長を促進する物質はこれまで知られていなかった. 私は野外で育てたアラスカエンド ウの茎や葉柄の切片を用い，その 1 次肥大生長が，IAA とカイネチンとの協同的作用によっていちじるし く促進されることを見出した.

カイネチンはIAAによる茎牱よび葉柄の伸長生長を抑制するが，肥大生長は，逆にいちじるしく促進す る.この促進は, 顕微鏡観察によれば, 茎の表皮, 皮層, 特よび髄の細胞の容積の增加によるものであっ て，細胞の数の増加によるものではない.

茎では光照射によって，伸長生長は抑制され，肥大生長は促進されることが，これまで知られていたが， カイネチンは茥の生長に和いて光とよく似た作用を有することが見出された.（武蔵大学生物学教室） 